\title{
Well-being and health perception of university students in Portugal: the influence of parental support and love relationship
}

\begin{abstract}
BACKGROUND
The mental health of university students has been the subject of great attention from scientific investigations, not only to provide contextualised information, but additionally since high levels of well-being predicted a quality education. This study aims to evaluate the perception of well-being and health of university students, exploring the psychometric properties of the Well-being and Health Perception Scale (WbHPS) and analysing the influence of sociodemographic variables.
\end{abstract}

\section{PARTICIPANTS AND PROCEDURE}

A questionnaire was applied to a representative sample of 840 university students in Portugal stratified by year of academic attendance and scientific area of study. The WbHPS consists of 5 items measured on a 5-point Likert scale. We considered as explanatory variables the year of study and scientific area, sex, age, love relationship, professional situation and BMI.
RESULTS

The WbHPS showed good psychometric properties, indicating the presence of an explanatory factor of $58.45 \%$ of variance and a good internal consistency $(\alpha=.81)$. The obtained results identified WbHPS as being independently associated with being in a love relationship, having a normal weight and not being displaced after starting at university.

\section{CONCLUSIONS}

It is necessary to (re)think about disease prevention and health promotion actions in higher education, with psychosocial interventions that truly reflect on the well-being and health of university students.

\section{KEY WORDS}

higher education; happiness; life satisfaction

ORganization - 1: Institute of Education, University of Minho, Braga, Portugal · 2: Department of Clinical Psychology and Psychobiology, University of Santiago de Compostela, Santiago de Compostela, Spain

Authors' contributions - A: Study design - B: Data collection - C: Statistical analysis · D: Data interpretation ·

E: Manuscript preparation · F: Literature search · G: Funds collection

CORRESPONDING Author - Regina F. Alves, Ph.D. Student; MSc., Research Centre on Child Studies (CIEC), Institute of Education, University of Minho, Campus de Gualtar, 4710-057 Braga, Portugal, e-mail: rgnalves@gmail.com 


\section{BACKGROUND}

Subjective well-being (SWB), in general terms, is an assessment, both cognitive and affective, of one's own existence, the inner experience of each individual who makes a judgment of how he or she feels, or his or her degree of satisfaction with life.

The concept of SWB as a complex concept does not have a definition reached by consensus (Diener, Suh, Lucas, \& Smith, 1999); however, most researchers agree that the study of SWB should comprise both cognitive and affective dimensions (Diener, Napa-Scollon, Oishi, Dzokoto, \& Suh, 2000; Galinha \& Ribeiro, 2005; Albuquerque \& Tróccoli, 2004). The cognitive dimension of SWB is reflected in the cognitive judgment of life satisfaction, while the affective dimension is presented as descriptions of the emotional state, and may be related to pleasant (positive emotions) and unpleasant (negative emotions) feelings, both in specific terms and, overall, with happiness (Galinha \& Ribeiro, 2005; Albuquerque \& Tróccoli, 2004; Diener et al., 1999; Rojas \& Elizondo-Lara, 2012). In other words, SWB is related to self-satisfaction and different areas of life, as well as a more holistic assessment, called overall life satisfaction or vital satisfaction.

Life satisfaction is a construct that refers to the contentment one feels in thinking about one's life as a whole (Bardagi \& Hutz, 2010), subjective assessments or judgments that the individual makes regarding their experiences, if they have provided (dis) satisfaction with life. To this end, the individual compares the circumstances of life with a set of self-imposed standards and the extent to which their quality of life corresponds to those standards. Thus, according to Pavot and Diener (2009) and Diener, Inglehart, and Tay (2013), life satisfaction is a conscious cognitive judgment of life in which the judgment criteria are personal. In practical terms, individuals with high well-being should have a high degree of satisfaction with life and positive emotions and low levels of negative emotions.

As already mentioned, other important indicators for measuring SWB refer to the concept of subjective happiness, that is, the individual's perceptions of happiness or positive effects (Lyubomirsky \& Lepper, 1999; Trinh \& Khanh, 2019), the quality of life defined as the perception of an individual about his position in life, in the context of his culture and the value systems in which he lives, and in relation to his goals, expectations, standards and concerns (The WHOQOL Group, 1995). From this perspective, the definitions in the literature of health-related quality of life, life satisfaction, SWB and happiness suggest a conceptual overlap (Camfield \& Skevington, 2008), and these dimensions are closely related (Medvedev \& Landhuis, 2018).

Emerging adulthood, considered a new life transition phase in which university students are included, is viewed as a time of exploration and experimentation (Arnett, 2000). This phase, by itself, can be a stage of the life cycle that is somewhat troubled, in which individuals are more independent in relation to parental control, but still free from commitments and responsibilities (Arnett, 2000). In addition, entry into higher education includes psychosocial development and a stage that leads to a number of new and sometimes adverse situations that can have negative repercussions (Abdel-Khalek, 2013; Auerbach et al., 2016; Demirli, Türkmen, \& Arık, 2015; Feldman \& Dreher, 2012; Molina et al., 2012; Pedrelli, Nyer, Yeung, Zulauf, \& Wilens, 2015; Stoyles, Chadwick, \& Caputi, 2015) on academic performance and the entire teaching-learning process (American College Health Association, 2018; Bücker, Nuraydin, Simonsmeier, Schneider, \& Luhmann, 2018; Fernández, Araújo, Vacas, Almeida, \& González, 2017; Ratelle, Simard, \& Guay, 2013).

Additionally, these can have effects on general well-being, contributing to an increase in depression, licit and illicit drug abuse and eating disorders in college students (Auerbach et al., 2016; Benotsch, Koester, Luckman, Martin, \& Cejka, 2011; Hingson, Zha, \& Weitzman, 2009; Monahan, Bracken-Minor, McCausland, McDevitt-Murphy, \& Murphy, 2012). In this climate, although they may be difficult to achieve, life satisfaction and happiness are extremely important aspects in the lives of college students, although difficult to achieve (Diener et al., 2000) and impacting their attitudes and behaviours (Khramtsova, Saarnio, Gordeeva, \& Williams, 2007).

Although entering higher education is a controversial period in its own right and deserves special attention, and many young adults suffer from psychological distress during their first year of college (Davidson, Feldman, \& Margalit, 2012), the study of well-being must be considered throughout the academic path. This is because other studies have shown that barriers to well-being, such as anxiety, stress and depression, increase with permanence in higher education (Beiter et al., 2015; Elias, Ping, \& Abdullah, 2011; Fawzy \& Hamed, 2017), with one in five university students reporting having an active mental illness (American College Health Association, 2018).

In this framework, this study aimed to analyse the psychometric properties of the Well-being and Health Perception Scale (WbHPS) and to explore predictors of WbHP among both first-year and thirdyear university students in Portugal.

\section{PARTICIPANTS AND PROCEDURE}

\section{PARTICIPANTS}

Data collection was carried out at a Portuguese university in the academic year 2018/2019. The total 
sample was estimated from a population of $5447 \mathrm{stu}-$ dents enrolled in the 1st and 3rd year of the undergraduate and master's degrees, according to a confidence interval of $95 \%$ and a maximum error of $3 \%$. For this purpose, stratified probabilistic sampling of university students was performed according to the year of study and the scientific area of study. In this sense, the different undergraduate and master's degrees were divided into scientific areas (as defined by the Foundation for Science and Technology): Human and social sciences, Law and economic sciences, Exact and natural sciences and Engineering sciences. Excluded from the sample were courses related to health sciences and postgraduate integrated masters or masters courses or those who did not have classes in the $1^{\text {st }}$ or $3^{\text {rd }}$ year.

The response rate was $96.2 \%$ (95\% CI 94.8-97.6), and 33 questionnaires were excluded for not being answered or incorrectly filled out. For reasons of proportionality with the target population, the majority of respondents were in the first year of study ( $n=464,55.2 \%)$ and were female $(n=465,55.4 \%)$. The sample of the present study mainly includes students who are not in a love relationship $(n=486$, $58.3 \%$ ), who changed residence at the time of entering higher education $(n=537,64.9 \%)$. In addition, the majority of respondents were full-time student ( $n=739,88.8 \%)$ and had a BMI corresponding to normal weight $(n=599,73.1 \%)$. The average age of the sample is $20.78(S D=4.22)$, ranging from 18 to 54 , and only $3 \%$ of the students are 30 years old or older.

\section{PROCEDURE}

WbHPS development was carried out in three stages: scale construction ( $1^{\text {st }}$ stage); content validity ( $2^{\text {nd }}$ stage); psychometric validity ( $3^{\text {rd }}$ stage). For the construction of the scale ( $1^{\text {st }}$ stage) we proceeded by consulting and analysing other instruments of SWB, quality of life and happiness for young adults and/or university students. Considering the various national and international instruments, an analytical matrix was created and questions or items were selected in the original form of the following instruments: the World Health Organization Quality of Life Instruments - BREF (WHOQOL-BREF; Vaz Serra et al., 2006); the Satisfaction With Life Scale (SWLS; Diener, Emmons, Larsen, \& Griffin, 1985); the Subjective Well-Being Scale (SWBS; Albuquerque \& Tróccoli, 2004); the Happiness Measure (HM; Fordyce, 1977, 1988), the Overall Life Satisfaction (OLS; Hutz, 2014); the Personal Wellbeing Index (PWI; Cummins, Eckersley, Pallant, van Vugt, \& Misajon, 2003); the Brief Multidimensional Students' Life Satisfaction Scale (BMSLSS; Huebner, Seligson, Valois, \& Suldo, 2006); the Oxford Happiness Questionnaire (OHQ; Hills \& Argyle, 2002); the single item Delighted-Terrible
Scale (Andrews, 1974), the Subjective Happiness Scale (SHS; Lyubomirsky \& Lepper, 1999); Self-Anchoring (Cantril, 1965); the Global Happiness Item (Bradburn, 1969). Then, the different items were divided according to the cognitive and affective dimension of SWB, and those with the same semantic similarities were eliminated.

Given the conceptual overlap of SWB and the literature review by Medvedev and Landhuis (2018), the items were grouped into different categories: quality of life, life satisfaction, self-satisfaction, happiness, health, positive and negative effects. From these dimensions, a response item was created for each of the dimensions, except for positive and negative effects, for the sake of measuring the predicted scale. Note that a 5-point Likert scale response format was adopted.

According to Diener and collaborators (2013), well-being scales can be influenced by factors such as the order of the questions, the importance attached to certain aspects, or social comparison. In constructing this scale we tried to control these effects. Thus, the definite order meant that respondents reflected primarily on their life in general, then moved on to specific situations such as selfsatisfaction. Additionally, information about health and finances, rather than only using information about social relationships or academic life, that is, considering all aspects of life, was used. In addition, the wording of certain items directed the answers to comparison with people of the same age, for example, "Compared with people your age, how do you rate your overall health?"

The scale in question was called the Well-being and Health Perception Scale (WbHPS), omitting the frequently used subjective term. The "subjective" descriptor delimits the construct indicating an assessment of life satisfaction from one's own perspective. And while this scale focuses on each individual's personal view of his or her own life, the statements in each of the items predict that assessment of well-being is not as subjective as on other scales analysed.

Then, for the content validity (2nd stage) $10 \mathrm{PhD}$ researchers from several Portuguese universities with recognized work in the area of Health Education in Higher Education were invited. For validity purposes, the feedback from 5 of the invited investigators was considered and all proposed semantic changes were considered. In the same way, the instrument was applied to 12 university students, using the "thinking aloud" method (Almeida \& Freire, 2008) to identify items that might be confusing and exclude less relevant or redundant items. In order to obtain greater objectivity, the following scale was used as the criterion of clarity evaluation for each item: 1 - confused; 2 - unclear; 3 - clear. The item related to quality of life was considered redundant
Well-being and health perception of university students 
Regina F. Alves, José A. G. Precioso,

Elisardo Becoña and was eliminated. Additionally, we reflected on the need to add an item related to satisfaction with physical form and lifestyle changes after entering higher education.

After the suggested restatements, the preliminary version of the WbHPS was presented to a sample of 32 students, with an average age of $22.12 \pm 5.98$ years. This pre-test was performed in order to observe the average filling time and possible inconsistencies due to possible misunderstanding of the questions. In this sense, it was found that the issues were understood and there were no misconceptions and no further linguistic changes were necessary. The scale obtained a Cronbach's $\alpha$ of .79, including the 6 scale items.

The questions of sociodemographic characterization included year of study and scientific area, sex, age, love relationship, weight and height (to calculate body mass index - BMI), current residence and professional situation.

The application of the instrument was performed in the classroom context for all students in the sample and in paper-and-pencil format for all students in the sample, after presenting the study objectives and informed consent. All ethical requirements for research procedures with human beings were met, and the present study was approved by the Ethics Committee for Research in Social and Human Sciences (CEICSH), of the University of Minho Ethics Council, under the protocol CEICSH 009/2019.

Data were analysed using IBM SPSS Statistics for Windows, version 25.0. The structure of the WbHPS scale was assessed by exploratory factor analysis (EFA) using the principal component analysis (PCA) method. For this, Bartlett's sphericity test was applied and the Kaiser-Meyer-Olkin (KMO) sampling adequacy measure was determined to test the validity of the factor analysis. The number of factors to be extracted was determined by the Kaiser criterion, considering the percentage of variance explained (Marôco, 2018). The factor loadings of each item and their commonalities (h2) were also evaluated. To evaluate the reliability of the scale, the item-total and

Table 1

Factorial load of each WbHPS item

\begin{tabular}{lc}
\hline WbHPS items & Factorial load \\
\hline Satisfaction with life & .84 \\
Self-satisfaction & .87 \\
Felt happiness & .81 \\
Perceived health & .61 \\
Satisfaction with physical form & .65 \\
Variance explained (\%) & 58.37 \\
\hline
\end{tabular}

inter-item correlation coefficients were calculated and for the internal consistency evaluation, Cronbach's $\alpha$ values were calculated.

A generalized linear model was developed including all sociodemographic variables with the intention of exploring possible predictors of well-being and health perception. A significance level of .05 was considered.

\section{RESULTS}

\section{PSYCHOMETRIC PROPERTIES OF THE SCALE}

Initially, a lifestyle changes item had been incorporated into the scale after entering higher education; however, after analysing the correlations and reliability of the construct, it was found that this item had a low correlation with the other items and that their exclusion from the scale increased the scale's reliability index. Thus, all analyses presented were performed for a scale of 5 items related to the dimensions: Satisfaction with life; Self-satisfaction; Felt happiness; Perceived health and Satisfaction with physical form. WbHPS showed good internal consistency $(\alpha=.81)$. Scale items had an item-total correlation between .47 and .74 and the Cronbach's $\alpha$ value if the item is eliminated between .73 and .81 . The item "Perceived Health" showed the least correlation with the scale, slightly increasing the value of Cronbach's $\alpha$ if it were eliminated. However, given its importance, we chose to keep it. Also, the interitem correlation coefficients for the scale ranged from .33 to .73 .

Before performing the factor analysis, the assumptions of homoscedasticity and sphericity were verified. In the sample, the KMO value was .79 and Bartlett's sphericity test was significant $\left(\chi^{2}(10)=1663.08, p<.001\right)$, showing that EFA is executable (Field, 2009).

The PCA results suggested the extraction of a factor that explains $58.4 \%$ of the explained variance, and the factor weights obtained ranged from .61 to .87 . The item "Perceived health" presented the lowest factor weight in the model presented (Table 1).

WbHPS is strongly correlated with all of its component items $\left(r_{\text {SATISFACTION LIFE }}=.77, p<.001, r_{\text {SELFSATISFAC- }}\right.$ TION $=.82, p<.001, r_{\text {FELT HAPPINESS }}=.72, p<.001, r_{\text {PERCEIVED }}$ HEALTH $\left.=.63, p<.001, r_{\text {PHYSICAL FORM }}=.72, p<.001\right)$.

Table 2 shows that the average for the 5 items that make up the scale ranged from $3.32(S D=1.01)$ to $3.89(S D=0.88)$, corresponding to the items "Satisfaction with physical form" and "Satisfaction with life", respectively. In this sense, $77.8 \%(n=652)$ of respondents indicated that they were satisfied or very satisfied with their life and $49.5 \%(n=415)$ with their physical form. The average WbHPS was $3.73 \pm 0.64$, ranging from 1 to 5 (Table 2). 


\begin{tabular}{|c|c|c|c|c|c|c|c|}
\hline & \multirow[t]{2}{*}{ M } & \multirow[t]{2}{*}{$S D$} & \multicolumn{5}{|c|}{$n(\%)$} \\
\hline & & & $\begin{array}{c}\text { Very } \\
\text { dissatisfied }\end{array}$ & Dissatisfied & $\begin{array}{c}\text { Neither } \\
\text { dissatisfied } \\
\text { nor } \\
\text { satisfied }\end{array}$ & Satisfied & $\begin{array}{c}\text { Very } \\
\text { satisfied }\end{array}$ \\
\hline Satisfaction with life & 3.89 & 0.88 & $18(2.1)$ & $49(5.8)$ & $119(14.2)$ & $475(56.7)$ & $177(21.1)$ \\
\hline Self-satisfaction & 3.72 & 0.94 & $24(2.9)$ & $78(9.3)$ & $143(17.1)$ & $543(54.1)$ & $140(16.7)$ \\
\hline \multirow[t]{2}{*}{$\begin{array}{l}\text { Satisfaction with } \\
\text { physical form }\end{array}$} & 3.32 & 1.01 & $31(3.7)$ & $160(19.1)$ & $232(27.7)$ & $337(40.2)$ & $78(9.3)$ \\
\hline & & & $\begin{array}{c}\text { Very } \\
\text { unhappy }\end{array}$ & Unhappy & $\begin{array}{c}\text { Neither } \\
\text { happy nor } \\
\text { unhappy }\end{array}$ & Happy & Very happy \\
\hline \multirow[t]{2}{*}{ Felt happiness } & 3.87 & 0.76 & $10(1.2)$ & $29(3.5)$ & $157(18.8)$ & $507(60.6)$ & $134(16.0)$ \\
\hline & & & Terrible & Bad & Reasonable & Good & Great \\
\hline Perceived health & 3.85 & 0.79 & $9(1.1)$ & $28(3.3)$ & $195(23.2)$ & $458(54.6)$ & $149(17.8)$ \\
\hline WbHPS & 18.66 & 3.32 & & & & & \\
\hline
\end{tabular}

Well-being and health perception of university students

\section{WBHPS ACCORDING TO SOCIODEMOGRAPHIC CHARACTERISTICS}

The bivariate analysis showed that the scientific area and year of study have no effect on students' perception of well-being and health $(F(3,829)=2.55, p>.05$, $t(831)=-1.00, p>.05)$. However, when considering the love relationship, current residence and BMI there were statistically significant differences of means between the different groups for each independent variable and WbHPS $(t(824)=4.13, p<.001, t(819)=-3.25$, $p<.001, F(3,809)=14.99, p<.001$, respectively $)$. This indicates that respondents currently in a love relationship have, on average, a greater perception of wellbeing and health compared to those who have no romantic relationship $(M=19.20 \pm 3.09, M=18.24 \pm 3.43$, respectively). Also, students who had not changed their residence after entering higher education $(M=19.96$ \pm 3.21 ) show higher well-being and health compared to students who had left their familial home $(M=18.17$ \pm 3.39 ). Considering BMI, it was concluded that students with BMI classified as overweight had a lower level of well-being and health $(M=17.47 \pm 3.28)$ compared to students with normal weight $(M=19.03$ $\pm 3.26)$ and with low weight $(M=18.28 \pm 3.01)$. Regarding the sex of respondents and professional situation, there were no statistically significant differences between groups as a function of WbHPS $(t(831)=1.84$, $p>.05, t(823)=-0.57, p>.05$, respectively).

Table 3 presents the associations between scores of WbHPS and other covariates. WbHPS was independently associated with having a love relationship, having normal weight and not being displaced after starting at university.

\section{DISCUSSION}

The results of this study suggest that WbHPS shows excellent psychometric properties, being characterized by good internal consistency and a single explanatory factor of $58.4 \%$ of variance. This corroborates with Diener et al. (1985), who point out that factorial analyses of multi-item life satisfaction scales often reveal a single underlying dimension. The WbHPS briefly and broadly presents its key advantages by assessing the domain of overall life satisfaction and the affective component of well-being.

The results revealed a significant proportion of students who are satisfied or very satisfied with their lives ( $n=652,77.8 \%$ ), results similar to other national (Bertoquini \& Pais-Ribeiro, 2006) and international studies (Arias-de la Torre, Molina, Fernández-Villa, Artazcoz, \& Martín, 2019b; Auerbach et al., 2016; Bardagi \& Hutz, 2010; Hardeman et al., 2015; Pedrelli et al., 2015; Storrie, Ahern, \& Tuckett, 2010). However, $22.8 \%$ of students were very dissatisfied or dissatisfied with their physical form, an aspect that should be considered when designing health education interventions.

In a meta-analysis by Wood, Rhodes, and Whelan (1989), it was found that women revealed more happiness than men. However, according to Marrero Quevedo, González Villalobos, and Carballeira 
Table 3

Standardized $\beta$-coefficients (generalized linear model - gamma regression) of multivariate analyses of the WbHPS scores according to other covariates $(n=840)$

\begin{tabular}{lcc}
\hline Predictors & $\operatorname{Exp}(\beta)$ & $95 \% \mathrm{Cl}$ \\
\hline $\begin{array}{l}\text { Year of study } \\
1^{\text {st }} \text { year }\end{array}$ & 0.98 & $0.98-1.03$ \\
$3^{\text {rd }}$ year & 1.00 &
\end{tabular}

Regina F. Alves, José A. G. Precioso, Elisardo Becoña

\section{Scientific area}

$\begin{array}{lcc}\text { Engineering Sciences } & 0.96 & 0.91-1.01 \\ \begin{array}{l}\text { Exact and Natural } \\ \text { Sciences }\end{array} & 0.99 & 0.93-1.06 \\ \begin{array}{l}\text { Law and Economic } \\ \text { Sciences }\end{array} & 0.98 & 0.92-1.04\end{array}$

Human and Social

Sciences

Sex

\begin{tabular}{|c|c|c|}
\hline Male & 0.99 & $0.96-1.02$ \\
\hline Female & 1.00 & \\
\hline Age (years) & 1.00 & $1.00-1.01$ \\
\hline \multicolumn{3}{|l|}{ Love relationship } \\
\hline Yes & $1.05^{* *}$ & $1.01-1.08$ \\
\hline No & 1.00 & \\
\hline \multicolumn{3}{|l|}{ Current residence } \\
\hline Displaced & $0.96^{*}$ & 0.93-0.99 \\
\hline Not displaced & 1.00 & \\
\hline \multicolumn{3}{|l|}{ BMI } \\
\hline Low weight & 1.05 & 0.93-0.99 \\
\hline Normal weight & $1.05^{* * *}$ & $0.99-1.11$ \\
\hline Overweight & 1.00 & \\
\hline \multicolumn{3}{|l|}{ Professional situation } \\
\hline Full time student & 1.02 & 0.97-1.07 \\
\hline Worker / Student & 1.00 & \\
\hline
\end{tabular}

Abella (2014), the most recent investigations show inconsistencies regarding the influence of gender on well-being. The present study did not reveal statistically significant differences between boys and girls, as were found in others studies (Bardagi \& Hutz, 2010; Barrantes-Brais \& Ureña-Bonilla, 2015).

In the sample of college students no significant differences were found between age or year of academic attendance and perception of well-being and health. These data differ from the few studies available, which seem to indicate a decrease in well-being levels along the academic path (Beiter et al., 2015; Bewick, Koutsopoulou, Miles, Slaa, \& Barkham, 2010; Fernández et al., 2017; Kovess-Masfety et al., 2016; Pedrelli et al., 2015; Rotenstein et al., 2016).

This study showed differences between the love relationship and the perception of well-being and health. As found in other scientific studies (Czyżowska, Gurba, Czyżowska, \& Kalus, 2020; Hills \& Argyle, 2002; Myers \& Diener, 1995; Ratelle et al., 2013), people in a loving relationship have a better perception of well-being and health. These data corroborate other international studies on well-being and happiness in college students by indicating that being in a loving relationship provides not only greater emotional stability but also greater well-being in all dimensions of life. (Diener et al., 1999; Lu, 2000; Marrero Quevedo et al., 2014).

The results indicated that non-displaced students have higher levels of well-being, as in other studies (Arias-de la Torre et al., 2019a; Fernández et al., 2017; Pedrelli et al., 2015; Rotenstein et al., 2016; Storrie et al., 2010). Family support continues to be one of the predictors of well-being for university students, both economically and emotionally. In line with the concept of emerging adulthood (Arnett, 2000), students are still free of the obligations inherent to adulthood and they are still dependent on their parents. In addition, if there was sufficient family support, this could help the individual develop their psychosocial and academic skills, free of financial responsibilities. Thus, it is important that in the processes of adaptation to higher education, implemented by universities, they consider strategies to improve family support (Aguayo et al., 2019; Claxton, Onwumere, \& FornellsAmbrojo, 2017; Kovess-Masfety et al., 2016).

The body mass index was considered a predictor of the model found in the present study. In this sense, it was found that overweight students showed a lower level of well-being than students with normal weight or underweight (Chen et al., 2016; Vankim \& Nelson, 2013).

Finally, the economic factor can be considered relevant to the achievement of the well-being of university students (Arias-de la Torre, Vilagut, Martín, Molina, \& Alonso, 2018), mainly due to the financial pressure on families (Arias-de la Torre et al., 2019b). On the other hand, being a student-worker can be a source of stress for the student (Aguayo et al., 2019). The multivariate analysis performed did not show the professional situation as a predictor of the level of well-being and health perception. This situation is different from other scientific studies with the university population, which show increased levels of psychological suffering caused by financial pressure (Barbaglia, Ten Have, Dorsselaer, Alonso, \& de Graaf, 2015; Kovess-Masfety et al., 2016). 


\section{LIMITATIONS AND FUTURE RESEARCH}

The most common limitations of this kind of welfare studies, and to which the present study is not immune, as reported by Eid and Larsen (2008), involve the transitions presented by mood states and contextual influences, which may affect participants' responses. However, throughout the data collection process, efforts were made to minimize these effects by collecting data in the classroom context, in different classes and at different times of the day.

The geographical restriction of the present study should be considered in this subsection, and the study should be extended to include other higher education institutions, as well as the study of the psychometric properties of the scale to other populations.

Another limitation concerns the study design. Its cross-sectional nature precludes causal interpretation. However, this study is the starting point for further analyses with a longitudinal perspective. In other words, future longitudinal research is needed to understand the impact of a year of study on wellbeing and health perception.

Finally, we believe that future research should consider lack of satisfaction with the decision to choose the field of study, the results that the student obtains during his studies and the participants' social support; their support from peers or friends. It is also important to take into account student activity in scientific, sports and other organizations at the university and beyond. In this sense, it is worth considering the division of variables: individual and relational (Trinh \& Khanh, 2019).

\section{CONCLUSIONS}

Well-being (subjective) is a construct made up of different but distinctly related clearing components. People with higher levels of perception of well-being and health tend to be healthier, happier and more satisfied.

The growing number of higher education welfare programmes underline the efforts of higher education institutions to improve the well-being and health of college students (Chow, 2005). This study identifies this need, reinforcing the urgency of creating disease prevention and health promotion actions, with psychosocial interventions that allow university students to reflect on their wellbeing and happiness, contributing to their holistic development.

The results indicate that it is necessary to (re) think about disease prevention and health promotion actions in higher education, with psychosocial interventions that truly reflect on the well-being and health of university students.

\section{REFERENCES}

Abdel-Khalek, A. M. (2013). The relationships between subjective well-being, health, and religiosity among young adults from Qatar. Mental Health, Religion \& Culture, 16, 306-318. https:// doi.org/10.1080/13674676.2012.660624

Aguayo, R., Cañadas, G., Assbaa-Kaddouri, L., Cañadas-De la Fuente, G., Ramírez-Baena, L., \& Ortega-Campos, E. (2019). A risk profile of sociodemographic factors in the onset of academic burnout syndrome in a sample of university students. International Journal of Environmental Research and Public Health, 16, 707. https://doi.org/10.3390/ ijerph 16050707

Albuquerque, A. S., \& Tróccoli, B. T. (2004). Desenvolvimento de Uma Escala de Bem-Estar Subjetivo [Development of a Subjective Well-Being Scale]. Psicologia: Teoria e Pesquisa, 20, 153-164. https:// doi.org/10.1590/S0102-37722004000200008

Almeida, L. S., \& Freire, T. (2008). Metodologia da investigação em psicologia e educação [Research methodology in psychology and education]. Braga: Psiquilíbrios.

American College Health Association (2018). American College Health Association - National College Health Assessment II: Undergraduate Student Reference Group Data report Fall 2018. American College Health Association. Retrieved from www. acha-ncha.org

Andrews, F. M. (1974). Social indicators of perceived life quality. Social Indicators Research, 1, 279-299. https://doi.org/10.1007/BF00303860

Arias-de la Torre, J., Fernández-Villa, T., Molina, A., Amezcua-Prieto, C., Mateos, R., Cancela, J., ... \& Martín, V. (2019a). Psychological distress, family support and employment status in first-year university students in Spain. International Journal of Environmental Research and Public Health, 16, 1209. https://doi.org/10.3390/ijerph 16071209

Arias-de la Torre, J., Molina, A. J., Fernández-Villa, T., Artazcoz, L., \& Martín, V. (2019b). Mental health, family roles and employment status inside and outside the household in Spain. Gaceta Sanitaria, 33, 235241. https://doi.org/10.1016/j.gaceta.2017.11.005

Arias-de la Torre, J., Vilagut, G., Martín, V., Molina, A. J., \& Alonso, J. (2018). Prevalence of major depressive disorder and association with personal and socio-economic factors. Results for Spain of the European Health Interview Survey 2014-2015. Journal of Affective Disorders, 239, 203-207. https:// doi.org/10.1016/j.jad.2018.06.051

Arnett, J. J. (2000). Emerging adulthood: a theory of development from the late teens through the twenties. American Psychologist, 55, 469-480. https://doi. org/10.1037/0003-066X.55.5.469

Auerbach, R. P., Alonso, J., Axinn, W. G., Cuijpers, P., Ebert, D. D., Green, J. G., ... \& Bruffaerts, R. (2016).
Well-being and health perception of university students 
Regina F. Alves, José A. G. Precioso, Elisardo Becoña
Mental disorders among college students in the World Health Organization World Mental Health Surveys. Psychological Medicine, 46, 2955-2970. https://doi.org/10.1017/S0033291716001665

Barbaglia, M. G., Ten Have, M., Dorsselaer, S., Alonso, J., \& de Graaf, R. (2015). Negative socioeconomic changes and mental disorders: a longitudinal study. Journal of Epidemiology and Community Health, 69, 55-62. https://doi.org/10.1136/jech-2014-204184

Bardagi, M. P., \& Hutz, C. S. (2010). Satisfação de vida, comprometimento com a carreira e exploração vocacional em estudantes universitários [Undergraduate students' life satisfaction, career commitment and career exploration]. Arquivos Brasileiros de Psicologia, 62, 159-170.

Barrantes-Brais, K., \& Ureña-Bonilla, P. (2015). Bienestar psicológico y bienestar subjetivo en estudiantes universitarios costarricenses [Psychological well-being and subjective well-being in Costa Rican university students]. Revista Intercontinental de Psicología y Educación, 17, 101-123.

Beiter, R., Nash, R., McCrady, M., Rhoades, D., Linscomb, M., Clarahan, M., \& Sammut, S. (2015). The prevalence and correlates of depression, anxiety, and stress in a sample of college students. Journal of Affective Disorders, 173, 90-96. https://doi. org/10.1016/j.jad.2014.10.054

Benotsch, E. G., Koester, S., Luckman, D., Martin, A. M., \& Cejka, A. (2011). Non-medical use of prescription drugs and sexual risk behavior in young adults. Addictive Behaviors, 36, 152-155. https://doi.org/10.1016/j.addbeh.2010.08.027

Bertoquini, V., \& Pais-Ribeiro, J. (2006). Estudo de formas muito reduzidas do modelo dos cinco factores da personalidade [Study of very small forms of the five personality factors model]. Psychologica, 43, 193-210.

Bewick, B., Koutsopoulou, G., Miles, J., Slaa, E., \& Barkham, M. (2010). Changes in undergraduate students' psychological well-being as they progress through university. Studies in Higher Education, 35, 633-645. https://doi.org/10.1080/03075070903216643

Bradburn, N. M. (1969). The structure of psychological well-being. Chicago, IL: Aldine.

Bücker, S., Nuraydin, S., Simonsmeier, B. A., Schneider, M., \& Luhmann, M. (2018). Subjective wellbeing and academic achievement: a meta-analysis. Journal of Research in Personality, 74, 83-94. https://doi.org/10.1016/j.jrp.2018.02.007

Camfield, L., \& Skevington, S. M. (2008). On subjective well-being and quality of life. Journal of Health Psychology, 13, 764-775. https://doi.org/ 10.1177/1359105308093860

Cantril, H. (1965) The pattern of human concerns. New Brunswick: Rutgers University Press.

Chen, W., Chen, B., Li, Q., Hua, M., Yu, S., \& Feng, H. (2016). Association of mental health with physical activity, BMI, and positive psychological wellbeing in college students. Medicine \& Science in Sports \& Exercise, 48, 1054. https://doi.org/10.1249/01. mss.0000488173.75017.69

Chow, H. P. H. (2005). Life satisfaction among university students in a Canadian prairie city: a multivariate analysis. Social Indicators Research, 70, 139-150. https://doi.org/10.1007/s11205-004-7526-0 Claxton, M., Onwumere, J., \& Fornells-Ambrojo, M. (2017). Do family interventions improve outcomes in early psychosis? A systematic review and metaanalysis. Frontiers in Psychology, 8, 371. https://doi. org/10.3389/fpsyg.2017.00371

Cummins, R. A., Eckersley, R., Pallant, J., van Vugt, J., \& Misajon, R. (2003). Developing a National Index of Subjective Wellbeing: The Australian Unity Wellbeing Index. Social Indicators Research, 64, 159-190. https://doi.org/10.1023/A:1024704320683

Czyżowska, D., Gurba, E., Czyżowska, N., \& Kalus, A. (2020). Intimate relationship and its significance for eudaimonic well-being in young adults. Health Psychology Report. https://doi.org/10.5114/ hpr.2020.93768

Davidson, O. B., Feldman, D. B., \& Margalit, M. (2012). A focused intervention for 1st-year college students: Promoting hope, sense of coherence, and self-efficacy. Journal of Psychology: Interdisciplinary and Applied, 146, 333-352. https://doi.org/ 10.1080/00223980.2011.634862

Demirli, A., Türkmen, M., \& Arık, R. S. (2015). Investigation of dispositional and state hope levels' relations with student subjective well-being. Social Indicators Research, 120, 601-613. https://doi. org/10.1007/s11205-014-0607-9

Diener, E., Emmons, R. A., Larsen, R. J., \& Griffin, S. (1985). The Satisfaction With Life Scale. Journal of Personality Assessment, 49, 71-75. https://doi. org/10.1207/s15327752jpa4901_13

Diener, E., Inglehart, R., \& Tay, L. (2013). Theory and validity of Life Satisfaction Scales. Social Indicators Research, 112, 497-527. https://doi.org/ 10.1007/s11205-012-0076-y

Diener, E., Napa-Scollon, C. K., Oishi, S., Dzokoto, V., \& Suh, E. M. (2000). Positivity and the construction of life satisfaction judgments: Global happiness is not the sum of its parts. Journal of Happiness Studies, 1, 159-176. https://doi.org/10.1023/ A:1010031813405

Diener, E., Suh, E. M., Lucas, R. E., \& Smith, H. L. (1999). Subjective well-being: Three decades of progress. Psychological Bulletin, 125, 276-302. https://doi. org/10.1037/0033-2909.125.2.276

Eid, M., \&, Larsen, R. J. (2008). The science of subjective well-being. New York: The Guilford Press.

Elias, H., Ping, W. S., \& Abdullah, M. C. (2011). Stress and academic achievement among undergraduate students in Universiti Putra Malaysia. Procedia - Social and Behavioral Sciences, 29, 646-655. https://doi.org/10.1016/j.sbspro.2011.11.288 
Fawzy, M., \& Hamed, S. A. (2017). Prevalence of psychological stress, depression and anxiety among medical students in Egypt. Psychiatry Research, 255, 186-194. https://doi.org/10.1016/j.psychres.2017.05.027

Feldman, D. B., \& Dreher, D. E. (2012). Can hope be changed in 90 minutes? Testing the efficacy of a single-session goal-pursuit intervention for college students. Journal of Happiness Studies, 13, 745-759. https://doi.org/10.1007/s10902-011-9292-4

Fernández, M. F. P., Araújo, A. M., Vacas, C. T., Almeida, L. S., \& González, M. S. R. (2017). Predictors of students' adjustment during transition to university in Spain. Psicothem, 29, 67-72. https:// doi.org/10.7334/psicothema2016.40

Field, A. (2009). Discovering statistics using SPSS. Los Angeles, CA: Sage.

Fordyce, M. (1977). The happiness measures: a sixty second index of emotional well-being and mental health. Retrieved from https://worlddatabaseofhappiness. eur.nl/hap_bib/freetexts/fordyce_mw_1983.pdf

Fordyce, M. W. (1988). A review of research on the happiness measures: a sixty second index of happiness and mental health. Social Indicators Research, 20, 355-381. https://doi.org/10.1007/BF00302333

Galinha, I., \& Ribeiro, J. L. P. (2005). História e evolução do conceito de bem-estar subjectivo [History and evolution of the concept of subjective wellbeing]. Psicologia, Saúde \& Doenças, 6, 203-214.

Hardeman, R. R., Przedworski, J. M., Burke, S. E., Burgess, D. J., Phelan, S. M., Dovidio, J. F., Nelson, D., Rockwood, T., \& van Ryn, M. (2015). Mental well-being in first year medical students: a comparison by race and gender. Journal of Racial and Ethnic Health Disparities, 2, 403-413. https://doi. org/10.1007/s40615-015-0087-x

Hills, P., \& Argyle, M. (2002). The Oxford Happiness Questionnaire: a compact scale for the measurement of psychological well-being. Personality and Individual Differences, 33, 1073-1082. https://doi. org/10.1016/S0191-8869(01)00213-6

Hingson, R. W., Zha, W., \& Weitzman, E. R. (2009). Magnitude of and trends in alcohol-related mortality and morbidity among U.S. college students ages 18-24, 1998-2005. Journal of Studies on Alcohol and Drugs, Supplement, 16, 12-20. https://doi. org/10.15288/jsads.2009.s16.12

Huebner, E. S., Seligson, J. L., Valois, R. F., \& Suldo, S. M. (2006). A review of the Brief Multidimensional Students' Life Satisfaction Scale. Social Indicators Research, 79, 477-484. https://doi.org/10.1007/s11205005-5395-9

Hutz, C. (2014). Avaliação em psicologia positiva [Evaluation in positive psychology]. Porto Alegre: Artes Médicas.

Khramtsova, I., Saarnio, D. A., Gordeeva, T., \& Williams, K. (2007). Happiness, life satisfaction, and depression in college students: Relations with stu- dent behaviors and attitudes. American Journal of Psychological Research, 3, 8-16.

Kovess-Masfety, V., Leray, E., Denis, L., Husky, M., Pitrou, I., \& Bodeau-Livinec, F. (2016). Mental health of college students and their non-collegeattending peers: Results from a large French crosssectional survey. BMC Psychology, 4, 20. https://doi. org/10.1186/s40359-016-0124-5

Lu, L. (2000). Gender and conjugal differences in happiness. The Journal of Social Psychology, 140, 132141. https://doi.org/10.1080/00224540009600451

Lyubomirsky, S., \& Lepper, H. S. (1999). A measure of subjective happiness: Preliminary reliability and construct validation. Social Indicators Research, 46, 137-155. https://doi.org/10.1023/A:1006824100041

Marôco, J. (2018). Análise estatística com o SPSS Statistics [Statistical analysis with SPSS Statistics]. Pêro Pinheiro: ReportNumber.

Marrero Quevedo, R. J., González Villalobos, J. Á., \& Carballeira Abella, M. (2014). Relación entre bienestar subjetivo, optimismo y variables sociodemográficas en estudiantes universitarios de la Universidad de San Luis Potosí en México [Relationship between subjective welfare, optimism and demographic variables in college students of the University of San Luis Potosi in Mexico]. Universitas Psychologica, 13, 1083-1098. https://doi. org/10.11144/javeriana.upsy13-3.rbso

Medvedev, O. N., \& Landhuis, C. E. (2018). Exploring constructs of well-being, happiness and quality of life. PeerJ, 6, e4903. https://doi.org/10.7717/peerj.4903

Molina, A. J., Varela, V., Fernández, T., Martín, V., Ayán, C., \& Cancela, J. M. (2012). Hábitos no saludables y práctica de actividad física en estudiantes universitarios Españoles: Papel del género, perfil académico y convivencia [Unhealthy habits and practice of physical activity in Spanish college students: The role of gender, academic profile and living situation]. Adicciones, 24, 319-327. https://doi. org/10.20882/adicciones.82

Monahan, C. J., Bracken-Minor, K. L., McCausland, C. M., McDevitt-Murphy, M. E., \& Murphy, J. G. (2012). Health-related quality of life among heavy-drinking college students. American Journal of Health Behavior, 36, 289-299. https:// doi.org/10.5993/AJHB.36.3.1

Myers, D., \& Diener, E. (1995). Who is happy? Psychological Science, 6, 10-19. https://doi.org/10.1111/j. 1467-9280.1995.tb00298.x

Pavot, W., \& Diener, E. (2009). Review of the Satisfaction With Life Scale. In E. Diener (Ed.), Assessing well-being: The collected works of Ed Diener (pp. 101-117). Dordrecht: Springer.

Pedrelli, P., Nyer, M., Yeung, A., Zulauf, C., \& Wilens, T. (2015). College students: Mental health problems and treatment considerations. Academic Psychiatry, 39, 503-511. https://doi.org/10.1007/s40596-0140205-9
Well-being and health perception of university students 
Regina F. Alves, José A. G. Precioso, Elisardo Becoña
Ratelle, C. F., Simard, K., \& Guay, F. (2013). University students' subjective well-being: The role of autonomy support from parents, friends, and the romantic partner. Journal of Happiness Studies, 14, 893-910. https://doi.org/10.1007/s10902-012-9360-4

Rojas, M., \& Elizondo-Lara, M. (2012). Satisfacción de vida en Costa Rica: Un enfoque de domínios de vida [Life satisfaction in Costa Rica: a life domain approach]. Latin American Research Review, 47, 78-94. https://doi.org/10.1353/lar.2012.0019

Rotenstein, L. S., Ramos, M. A., Torre, M., Segal, J. B., Peluso, M. J., Guille, C., Sen, S., \& Mata, D. A. (2016). Prevalence of depression, depressive symptoms, and suicidal ideation among medical students. JAMA, 316, 2214-2236. https://doi.org/10.1001/jama. 2016.17324

Storrie, K., Ahern, K., \& Tuckett, A. (2010). A systematic review: Students with mental health problems - a growing problem. International Journal of Nursing Practice, 16, 1-6. https://doi.org/10.1111/j.1440172X.2009.01813.x

Stoyles, G., Chadwick, A., \& Caputi, P. (2015). Purpose in life and well-being: The relationship between purpose in life, hope, coping, and inward sensitivity among first-year university students. Journal of Spirituality in Mental Health, 17, 119134. https://doi.org/10.1080/19349637.2015.985558

The WHOQOL Group (1995). The World Health Organization quality of life assessment (WHOQOL): Position paper from the World Health Organization. Social Science \& Medicine, 41, 1403-1409. https://doi.org/10.1016/0277-9536(95)00112-K

Trinh, L. T., \& Khanh, H. T. T. (2019). Happy people: Who are they? A pilot indigenous study on conceptualization of happiness in Vietnam. Health Psychology Report, 7, 1-9. https://doi.org/10.5114/ hpr.2019.88527

Vankim, N. A., \& Nelson, T. F. (2013). Vigorous physical activity, mental health, perceived stress, and socializing among college students. American Journal of Health Promotion, 28, 7-15. https://doi. org/10.4278/ajhp.111101-QUAN-395

Vaz Serra, A., Canavarro, M. C., Simões, M., Pereira, M., Gameiro, S., Quartilho, M. J., Rijo, D., Carona, C., \& Paredes, T. (2006). Estudos psicométricos do instrumento de avaliação da qualidade de vida da Organização Mundial de Saúde (WHOQOLBref) para Português de Portugal [Psychometric studies of the World Health Organization quality of life assessment instrument (WHOQOL-Bref) for Portuguese in Portugal]. Psiquiatria Clínica, 27, 41-49.

Wood, W., Rhodes, N., \& Whelan, M. (1989). Sex differences in positive well-being: a consideration of emotional style and marital status. Psychological Bulletin, 106, 249-264. https://doi.org/10.1037/00332909.106.2.249 